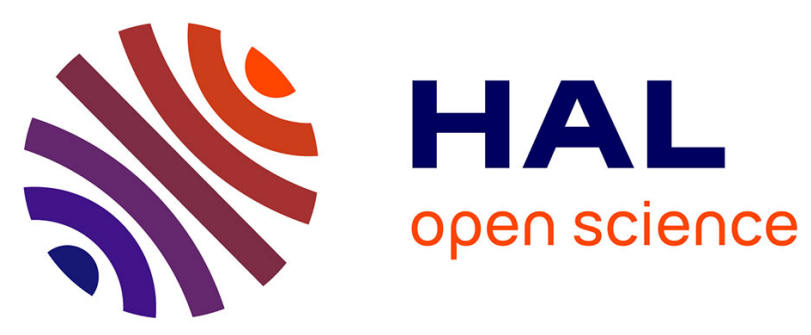

\title{
Assessment of long term ecotoxicity of urban stormwaters using a multigenerational bioassay on Ceriodaphnia dubia: A preliminary study
}

Antoine Gosset, Adriana Wigh, Sylvie Bony, Alain Devaux, Rémy Bayard, Claude Durrieu, Melissa Brocart, Marine Applagnat, Christine Bazin

\section{To cite this version:}

Antoine Gosset, Adriana Wigh, Sylvie Bony, Alain Devaux, Rémy Bayard, et al.. Assessment of long term ecotoxicity of urban stormwaters using a multigenerational bioassay on Ceriodaphnia dubia: A preliminary study. JOURNAL OF ENVIRONMENTAL SCIENCE AND HEALTH PART A-TOXIC/HAZARDOUS SUBSTANCES \& ENVIRONMENTAL ENGINEERING, 2018, 53 (3), pp.244-252. 10.1080/10934529.2017.1394722 . hal-01618107

\author{
HAL Id: hal-01618107 \\ https://hal.science/hal-01618107
}

Submitted on 17 Oct 2017

HAL is a multi-disciplinary open access archive for the deposit and dissemination of scientific research documents, whether they are published or not. The documents may come from teaching and research institutions in France or abroad, or from public or private research centers.
L'archive ouverte pluridisciplinaire HAL, est destinée au dépôt et à la diffusion de documents scientifiques de niveau recherche, publiés ou non, émanant des établissements d'enseignement et de recherche français ou étrangers, des laboratoires publics ou privés. 


\section{Assessment of long term ecotoxicity of urban stormwaters using a multigenerational bioassay on Ceriodaphnia dubia: A preliminary study}

Antoine Gosset ${ }^{1,3 *}$, Adriana Wigh ${ }^{1}$, Sylvie Bony ${ }^{1,2}$, Alain Devaux ${ }^{1,2}$, Rémy Bayard ${ }^{3}$, Claude Durrieu $^{1}$, Melissa Brocart ${ }^{1}$, Marine Applagnat ${ }^{1}$, and Christine Bazin ${ }^{4}$

$$
\begin{aligned}
& { }^{1} \text { Université de Lyon, ENTPE, CNRS, UMR } 5023 \text { LEHNA, } 2 \text { Rue Maurice Audin, } \\
& 69518 \text { Vaulx-en-Velin, France }
\end{aligned}
$$

${ }^{2}$ INRA, USC LEHNA 1369, ENTPE, F-69518 Vaulx-en-Velin, France

3Université de Lyon, INSA Lyon, DEEP Laboratory, EA7429, F-69621 Villeurbanne cedex, France

${ }^{4}$ PROVADEMSE, Boulevard Niels Bohr, CS 52132, 69603 Villeurbanne Cedex, France

*corresponding author. Antoine Gosset, Université de Lyon, ENTPE, CNRS, UMR 5023 LEHNA, 3 Rue Maurice Audin, 69518 Vaulx-en-Velin, France.

Tel.: +33 4720472 90; Fax: +334 72047743 .

E-mail address: antoine.gosset@entpe.fr

3

4




\section{ABSTRACT}

32

Standardized ecotoxicity bioassays show some limits to assess properly long-term residual toxicity of complex mixture of pollutants often present at low concentration, such as stormwaters. Among invertebrate organisms used for ecotoxicity testing, the microcrustacean Ceriodaphnia dubia (C. dubia) is considered as one of the most sensitive, especially regarding reproduction impairment as a toxicity endpoint. Consequently, the present work explores the interest to perform a multigenerational assay based on the study of the reproduction of $C$. dubia to assess long-term ecotoxicity of complex mixture, using stormwater samples. With this in mind, a battery of standardized bioassays (Daphnia magna mobility, Pseudokirchneriella subcapitata population growth, Heterocypris incongruens growth and one generation $C$. dubia reproduction inhibition assays) was performed in parallel to a three generation $C$. dubia reproduction inhibition assay on 2 stormwater samples. Results highlighted that while all standardized bioassays failed to reveal residual toxicity in the stormwater samples, the $C$. dubia multi-generational assay exhibited an higher sensitivity than the previous ones. No adverse effect was observed for the first exposed generation, but an increase in mortality and a reproduction disturbance was obtained in the second and third exposed generation depending of the sample. Further experiments are now needed to optimize the exposure protocol of this multigenerational assay.

KEYWORDS: Stormwater; Bioassay battery; Daphnid reproduction; life-history trait; Multigenerational; Micropollutant 


\section{INTRODUCTION}

\section{(2)}

In Europe, the Urban Wastewater Directive (91/271/EEC) requires the management of all urban wastewaters i.e. effluents and stormwaters, even though available treatments (mainly retention and/or infiltration basins) are relatively limited in efficiency notably due to the large volumes to be treated. Furthermore, European Water Framework Directive (EWFD, 2000/60/EC) requires to maintain the good ecological status of water bodies receiving such effluents. To achieve this goal, it remains of value to implement effective monitoring methods such as bioassays likely to reveal the residual ecotoxicity of chemically complex mixtures of contaminants at low concentrations such as stormwater.

Many standardized bioassays are currently used to assess the ecotoxicity of urban stormwaters. 24-h Daphnia magna (D. magna) immobilization, 72-h Pseudokirchneriella subcapitata (P. subcapitata) growth, 6-d Heterocypris incongruens (H. incongruens) and 7-d Lemna minor (L. minor) growth assays are the most common ones. However, it has been shown that such standardized bioassays often fail to properly assess stormwater toxicity, mainly due to their low contamination level, and/or to the presence of nutrients interfering with the measured endpoint, in particular growth. ${ }^{[1,2]}$ Angerville et al. ${ }^{[1]}$ showed that $C$. dubia reproduction bioassay was the most sensitive to assess the toxicity of this kind of matrixes. Moreover, previous studies using cladocerans (D. magna) highlighted that many environmental pollutants (pesticides, heavy metals, pharmaceuticals, phthalates, ...) led to reproduction impairment with different modes of toxic action: estrogenic and antiestrogenic, androgenic and anti-androgenic activities through activation/blocking of specific receptors, modulation of steroid metabolism (others than estrogens and androgens), disturbance of ecdysis or juvenile hormone mimicry. ${ }^{[3,4,5]}$ Endocrine disrupting activities can lead to adverse effects on exposed organisms, but also on their progeny, creating adverse effects on subsequent generations. ${ }^{[6,7]}$ Nowadays, there is undoubtedly an important concern about the long term ecotoxicity assessment of single chemicals and of multi-contaminated matrixes and the scientific community is actively working 
to create harmonization (OECD guidelines) of multigenerational bioassays on cladocerans (D. magna) to detect long-term impairments, as done recently by Barata et al. ${ }^{[6]}$

Multigenerational ( 3 to 5 generations) reproduction inhibition tests have already been developed on $C$. dubia. Rose et al. ${ }^{[8,9]}$ used such an approach for testing the long-term reproduction toxicity of low concentration of 3,4-dichloroaniline (3,4 DCA), a by-product of the herbicide diuron. These authors observed that 3,4-DCA at environmentally realistic concentrations led to a stimulation of the reproduction (overproduction of neonates) starting at the second generation exposed (total of 4 generations studied), resulting in tolerance (physiological acclimation or genetically-based resistance) to $3,4 \mathrm{DCA}$ at concentration up to $2.5 \mu \mathrm{g} / \mathrm{L}$. On the contrary, Lamichhane et al. ${ }^{[10,11]}$ observed that two pharmaceuticals (carbamazepine and sertraline) led to a decrease in offspring production in three successive $C$. dubia generations exposed respectively to 196.7 and $4.8 \mu \mathrm{g} / \mathrm{L}$.

The main objective of this study was to implement an ecotoxicological battery of bioassays, comprising D. magna acute bioassay and $P$. subcapitata, H. incongruens and $C$. dubia chronic bioassays, as well as a multigenerational bioassay carried out on $C$. dubia, to assess the toxicity of two stormwater effluents. For the later, $C$. dubia reproduction assay was derivated from the standardized bioassay (NF ISO 20665 ${ }^{[12]}$ ) and applied in three successive generations in order to assess with a good reliability a possible long-term toxicity of urban stormwater samples collected.

\section{MATERIALS AND METHODS}

\section{Sampling Sites}

Two samples of stormwaters were collected. The first one (CHA) stemming from a sub-urban zone of Lyon City (France), corresponded to the outfall of a retention-infiltration basin receiving stormwater from a highly urbanized industrial area of 185 ha, with an imperviousness rate of $75 \% .^{[13]}$ The second one (MIR) was collected in the overflow of three interconnected retention ponds, in the 
North-East of Lyon City corresponding to a small watershed of 11 ha draining a sub-urban area under high agricultural pressure. The two samples were collected between March and April 2015 and the main characteristics of the corresponding storm events are summarized in Table 1. Grab stormwater samples were collected manually during the storm events, using 2L highdensity polyethylene flasks previously washed three times with the discharge. Samples were transported immediately to the laboratory and was filtered $(0.45 \mu \mathrm{m}$ pore size $)$ or not, depending on the assay. Then, $120 \mathrm{~mL}$ aliquots (filtered and non-filtered) were stored at $-20^{\circ} \mathrm{C}$ until testing.

\section{Tab 1}

\section{Physico-Chemical Analyses of Samples}

Several physico-chemical parameters (pH, Conductivity, Dissolved Organic Carbon (DOC), Total suspended Solids (TSS), etc.) were measured according to European standards as described by Angerville et al. ${ }^{[1]}$ Using $0.45 \mu \mathrm{m}$ filtered samples, a total of 102 organic compounds were analyzed by an accredited laboratory (CARSO laboratory in Venissieux) according to European standards (34 pesticides, 15 Polycyclic Aromatic Hydrocarbons (PAHs), 22 Volatile Organic Compounds (VOCs), 16 Benzene derivatives, 12 Phenol derivatives and 3 others). A list of all organic compounds and analytical methods employed are summarized in Supplementary Table 1. Additionally, eight major metals $(\mathrm{Pb}, \mathrm{Cr}, \mathrm{Ni}, \mathrm{Cd}, \mathrm{Cu}, \mathrm{Fe}, \mathrm{Ca}$ and $\mathrm{Zn}$ ) were analyzed by ICP-MS (Hitachi spectrophotometer).

\section{Algal (Pseudokirchneriella subcapitata) Culture and Growth Inhibition Test}

The algal strain was purchased from the French National Museum of Natural History (Paris, France). P. subcapitata were cultured in Lefebvre-Czarda medium. ${ }^{[14]}$ Algae cultures were transplanted weekly under sterile condition, using sterilized glassware and medium (autoclaved during $20 \mathrm{~min}$, at $130{ }^{\circ} \mathrm{C}$, under $1.3 \mathrm{bar}$, with the aim of using fresh algae in their growth phase. Algae were maintained $21^{\circ} \mathrm{C}$ in a culture room under a 16h/8h light/dark cycle (5000 lux illumination). Growth inhibition assays 
were realized following the OECD guidelines, ${ }^{[15]}$ and $\mathrm{EC}_{20} 72 \mathrm{~h}$ values were calculated using the Hill probit model (Regtox ${ }^{\circledR}$, E. Vindimian, http://normalesup.org/ vindimian/).

\section{Ostracode (Heterocypris Incongruens) Lethality And Growth Inhibition Test}

A 6-day subchronic toxicity test was conducted following the NF EN ISO 14371 standard. ${ }^{[16]}$

Organisms were exposed to $50 \%$ (standard value) or to $95 \% \mathrm{v} / \mathrm{v}$ of stormwater with minor modifications. Briefly, test was carried out using the OSTRACODTOXKIT F®. Cysts were kept for $48 \mathrm{~h}$ in standard freshwater at $25^{\circ} \mathrm{C}$ and under a $3000-4000$ lux illumination to hatch. Ten $4 \mathrm{~h}$-post hatching neonates ( 6 replicates of 10 organisms) were sampled and their survival and body length were measured after 6-day exposure using the image analysis Motic ${ }^{\circledR}$ software.

\section{Cladoceran Stock Culture}

Water flea D. magna and C. dubia (IRSTEA, France) were bred (weekly transplantation, continuous parthenogenetic reproduction) in two liter glass jars, under 500 \pm 200 lux illumination and at a temperature of $25 \pm 2^{\circ} \mathrm{C}$ for $C$. dubia and at $20 \pm 2{ }^{\circ} \mathrm{C}$ for D. magna, under a $16 \mathrm{~h}$ light/8h dark photoperiod. D. magna was cultured in Volvic ${ }^{\circledR}$ water. C. dubia was cultured in Evian ${ }^{\circledR}$ water supplemented by $75 \mu \mathrm{g} / \mathrm{L}$ thiamine chlorhydrate, $1 \mu \mathrm{g} / \mathrm{L}$ cyanocobalamine and $0.75 \mu \mathrm{g} / \mathrm{L}$ biotine. According to the NF EN ISO 20665 standard, ${ }^{[12]}$ organisms were daily fed on P. subcapitata algae culture $\left(40.10^{6}\right.$ cells $\left./ \mathrm{mL}\right)$ and on fish food $\left(2.5 \mathrm{~g} / \mathrm{L} \mathrm{JBL}\right.$ NovoRed ${ }^{\circledR}$ solution $)$.

\section{Daphnia Magna Mobility Inhibition Test}

The mobility inhibition bioassay ( 24 and $48 \mathrm{~h}$ acute toxicity test) was conducted following the NF EN ISO 6341 standard. ${ }^{[17]} \mathrm{EC}_{20}$ values were calculated using the Hill probit model (Regtox ${ }^{\circledR}$ ). 
C. dubia reproduction test was performed on three successive generations following a modified

157

158

159

160

161

162 protocol derived from the standardized one generation-reproduction bioassay NF ISO 20665. ${ }^{[12]}$ Due to the rather small volume of stormwater samples available, bioassay was developed and conducted in 6-well plates. In each well, one organism was exposed during 10 days in $10 \mathrm{~mL}$ (instead of using 50 $\mathrm{mL}$ in the ISO standard) of either $0.45 \mu \mathrm{m}$ filtered stormwater sample at a concentration of $90 \%(\mathrm{v} / \mathrm{v})$ or to the control medium (see 2.5). Main physico-chemical characteristics ( $\mathrm{pH}$ and conductivity) of control medium and of tested stormwaters were in the same range what enabled to expose organisms up to $90 \%$ of stormwater. Exposure medium consisted of $9 \mathrm{~mL}$ of sample (stormwater or control water) mixed with $1 \mathrm{~mL}$ of $C$. dubia food suspension. Exposure medium was renewed every two days with thawed stormwater in order to insure constant exposure conditions. Twelve replicate organisms were used per tested condition, each replicate consisting of one neonate (age $<24 \mathrm{~h}$ ) obtained from the stock culture of $C$. dubia and considered as the first generation (F0). Every two days when exposure medium was renewed, neonates were counted and removed. Organisms were then fed and parent mortality measured. Neonates from the second brood (of the twelve replicates) were mixed and randomly used to produce the next generation (F1) exposed again to the wastewater samples or to the control medium. Experiment was repeated for three successive generations (Figure 1). Two parameters were followed at each generation (i.e. after 10 days of exposure): first, the population growth expressed as the total number of neonates per mother (sum of neonates produced along the successive broods), and second, the reproduction success expressed as the number of neonates per alive mother at each generation, enabling to take into account a possible effect of mother mortality on reproduction success. Regarding the NF ISO 20665 standard, a reproduction inhibition and a mortality lower than 30 and $20 \%$ respectively, were considered as non-significant. 


\section{Statistical Analysis}

181

182

183

184

185

186

187

188

189

190

191

192

193

194

195

196

197

198

199

200

201

202

203

204

Data from H. incongruens and C. dubia assays were analyzed using GraphPad Prism version 7 for

Windows (GraphPad software, San Diego, CA, USA). Distribution normality and homoscedasticity were tested for each parameter using Shapiro-Wilk and Brown-Forsythe tests. When these conditions were respected, comparisons between groups were carried out using the ANOVA test followed by post-hoc tests, and if not, by using the non-parametric Kruskal-Wallis test followed by post-hoc tests.

\section{RESULTS}

\section{Chemical Analyses}

Table 2 illustrates physico-chemical analyses of the stormwaters. Metal concentrations were lower than the Predicted No Effect Concentration (PNEC) values established by INERIS (National Institute for the Industrial Environment and Risks, France), except for copper and zinc. Regarding organic micropollutants, some pesticides were detected in the $\mu \mathrm{g} / \mathrm{L}$ range: for example the fungicide fosetylaluminium in CHA sample $(2.6 \mu \mathrm{g} / \mathrm{L})$, the herbicide glyphosate $(69.25 \mu \mathrm{g} / \mathrm{L}$, higher than the PNEC value) and one of its degradation by-product AMPA (acide 2-amino-3-(5-méthyl-3-hydroxy-1,2oxazol-4-yl)propanoïc) in MIR sample (20.15 $\mu \mathrm{g} / \mathrm{L})$. In CHA sample, two other organic pollutants, benzyl chloride and tributyl phosphate, were detected but concentration remained below their PNEC values. Other compounds, such as the PAH fluorene, were found in both samples. All other compounds among the 105 analyzed were under their limit of quantification.

\section{Tab 2}

\section{D. magna, P. subcapitata And H. incongruens Bioassays}

As illustrated in Table 3, $\mathrm{EC}_{20}$ value was above $90 \%$ whatever the stormwater sample, suggesting a lack of acute toxicity towards D. magna (24 and 48 hours of exposure), as well as towards $\underline{P}$. $\underline{\text { subcapitata }}$ (72h exposure). 
Results of the ostracod growth assay are presented in Figure 2. After exposure to a $50 \%$ stormwater concentration, ostracod growth was not significantly affected neither by CHA nor by MIR sample. With $95 \%$ of sample in the exposure medium, both samples led to a slight growth stimulation (p < 0.05). No mortality was observed at the end of the assay.

\section{Fig 2}

\section{C. dubia Multigenerational Bioassay}

\section{Validation of the method}

The NF ISO 20665 standard requires some validation criteria for the reproduction C. dubia bioassay in control exposure conditions: less than $20 \%$ mortality of parents, at least three broods at the end of exposure for $60 \%$ of the parents, less than $20 \%$ of males in parent generation and at least 15 neonates produced per parent. As presented in Table 4, mortality of parents at each generation remained null in the control. Furthermore, no male was detected whatever the generation. It must be stressed that probably due to the reduction of the exposure volume $(10 \mathrm{~mL} v s 5 \mathrm{~mL})$, the number of broods and neonates produced per mother did not respect the standard. However, values remained closed to the requested criteria $(2.33 ; 3.33$ and 3 broods per mother; $11.1 ; 10.7$ and 12.5 neonates per mother for F1, F2 and F3 generations respectively).

\section{Tab 4}

\section{First generation effect on Ceriodaphnia dubia}

Studying the first generation of $C$. dubia corresponds to the standard chronic reproduction bioassay, despite minor modifications applied to the protocol as stated before. In control and in exposed organisms, mortality of the parents was under or equal to $8.3 \%$, and consequently was considered as not significant. Responses of $C$. dubia to the different stormwater samples are given in Figure 3 and 
Table 4. No chronic toxicity (population growth and reproduction) was observed at the first exposed generation $(\mathrm{F} 1)$.

\section{Second and third generations}

CHA stormwater sample led to a strong inhibition of $C$. dubia population growth (60.81\% of control) and of reproduction (53.14\% of control) at the second generation F2 (p-value $=0.0151$ and pvalue $=0.0 .0188$, respectively), and to a high parent mortality rate $(54.54 \%$ increase compared to control). On the contrary, a significant stimulation of both growth and reproduction was obtained at the third generation (F3) of daphnids exposed to CHA stormwater (Figure 3).

An opposite trend was observed after exposure to MIR stormwater sample, i.e. a significant stimulation of reproduction $(38.71 \%)$ at generation F2 (p-value=0.0347) and a high and significant inhibition at the third generation $(\mathrm{F} 3)$ regarding both population growth $(64.67 \%$ p-value $<0.0001)$ and reproduction (52\%; no statistics possible because of the high parent mortality rate $(80 \%)$ resulting in only 2 available replicates).

\section{DISCUSSION}

Fig 3

Chemical analyses (realized once and considered representative of the 10 day-exposure since medium was renewed every other day) show that for the two sampled stormwaters, several pollutants were detected, the chemical pattern depending on the characteristics of the corresponding watershed. Concerning organic micropollutants, their presence can be easily explained by the different human activities along the watersheds studied. Here, high concentration of glyphosate, regarding its PNEC value, and of AMPA (respectively 69.25 and $20.15 \mu \mathrm{g} / \mathrm{L}$ ) found in MIR sample may be related to a high agricultural pressure in the corresponding watershed. For the CHA sample, the presence of tributyl phosphate and of benzyle chloride could arise from plastics and wood industry settled in the Chassieu industrial area. Moreover, heavy metals (here $\mathrm{Cu}, \mathrm{Cd}, \mathrm{Cr}, \mathrm{Ni}$ or $\mathrm{Zn}$ ), and PAHs (here 
255 fluorene) are commonly found in urban stormwater discharges, ${ }^{[18,19]}$ due to road traffic, vehicle brake emissions and atmospheric depositions.

The absence of acute toxicity in D. magna. (mobility) observed in both samples tested is in accordance with previous results of Waara et al. ${ }^{[20]}$, Angerville et al. ${ }^{[1]}$, or Bi et al. ${ }^{[21]}$, obtained after exposure to urban wet weather discharges, confirming the tendency that acute toxicity bioassays are not enough sensitive for stormwater toxicity evaluation.

When conducting standard chronic assays with algae and ostracods, no toxicity was observed either. A slight growth stimulation of $H$. uncongruens was even recorded when organisms were exposed to $95 \%$ of MIR or CHA sample. Although not commonly described in the case of stormwaters, such an effect was observed by Wigh et al. ${ }^{[22]}$ with wastewater effluents stemming from a treatment plant. Several authors as Sterner ${ }^{[23]}$, Elser et al. ${ }^{[24]}$ or Civitello et al. ${ }^{[25]}$ have suggested that enrichment due to nutrients such as phosphorus and nitrogen can stimulate the growth of producers and consumers and their reproduction. Here, nutrients could have contributed to stimulate the microalgal growth and consequently, to increase the amount of available food for primary consumers (e.g. 7.0 mg. $\mathrm{L}^{-1} \mathrm{NO}_{3}{ }^{-}$in MIR sample dissolved phase). .

The main objective of the present work was to overcome the issues encountered in the ecotoxicity assessment of complex matrixes such as stormwater with standardized methods. Therefore, a $C$. dubia multigenerational assay was performed. The choice of this organism and of reproduction as an end point was driven by previous results obtained in our laboratory by Angerville et al. ${ }^{[1]}$ They observed that $C$. dubia reproduction bioassay was the most sensitive one among a rather broad ecotoxicity test battery applied to urban combined sewer overflows (acute bioassays on : Vibrio Fischeri, D. magna, Danio rerio ; chronic bioassays on : P. subcapitata, D. magna, Brachionus calyciflorus, C. dubia).

The novelty of the assay performed here is the threefold repetition (i.e. on 3 successive generations) of the one generation NF ISO 20665 assay in a miniaturized version (10 vs $50 \mathrm{~mL}$ exposure volume). This was done in an attempt to evaluate long term toxic events. Sufficient fulfilment of most of the 
validity criteria supported by the standardized method was achieved excepted for the number of brood that was slightly lower than three in average. In 2003, Pandard. ${ }^{[26]}$ attempted to perform the C. dubia reproduction assay in $25 \mathrm{~mL}$ instead of $50 \mathrm{~mL}$ and described the same trend. This point certainly deserves further improvements or a reevaluation of a minimum valid brood number in the perspective of a refined assay.

As performed here, one can first stress that the $C$. dubia reproduction bioassay carried out with stormwater samples did not highlight any significant toxic effect (mortality or reproduction impairment) at the first generation. This result is in accordance with the studies of Kayhanian et al. ${ }^{[27]}$, McQueen et al. ${ }^{[28]}$ and Angerville et al..$^{[1]}$, showing with the standardized assay that for a majority of urban runoffs samples, no effect was detected after one single $C$. dubia generation exposure. As hypothesized, when second and third generations were exposed, acute and chronic toxicity appeared after both MIR and CHA sample exposure. Two kinetics of toxicity response of $C$. dubia were obtained: the one observed after exposure to MIR sample, is a stimulation of population reproduction at the second generation followed by an acute toxicity and reproduction impairment at the third generation. The second one observed after exposure to CHA sample, is a possible resistance/acclimation of organisms at the third generation, expressed as a stimulation of reproduction in F2 mothers, after an increase in mortality and reproduction inhibition measured at the second generation. Caution must be taken when considering the physico-chemistry of the samples to explain such results because of the possible interaction between chemicals and the fact that chemical analysis is limited to some compounds. Nevertheless, regarding MIR sample we can hypothesize that the results could be partially related to the presence of glyphosate and its degradation product AMPA, glyphosate concentration being much higher than its PNEC value. This herbicide disturbs aromatase activity involved in the synthesis of estrogens and thus has been identified as an endocrine disruptor. ${ }^{[29]}$ Cuhra et al. ${ }^{[30]}$ observed a reduction of the fecundity and an increased abortion rate (determined counting the number of aborted eggs along the time) after exposure to $1.35 \mathrm{mg} / \mathrm{L}$ of glyphosate and a reduction of offspring length at lower concentrations $(50 \mu \mathrm{g} / \mathrm{L})$ in $D$. magna. Trends observed after CHA sample exposure are more complex to interpret, but heavy metals could be responsible for the observed effects. Chemical analyses (Table 2) showed rather high concentrations of 
heavy metals regarding their PNEC values (in particular $\mathrm{Cu}$ and $\mathrm{Zn}$, at respectively 12.48 and 80 $\mu \mathrm{g} / \mathrm{L}$ ). Cooper et al. ${ }^{[31]}$ observed that a mixture of the three metals $\mathrm{Cu}, \mathrm{Pb}$, and $\mathrm{Zn}$ could lead to a significant reproduction impairment on 7-days exposed C. dubia at concentrations of $1.3(\mathrm{Cu}), 1.1$ $(\mathrm{Pb})$ and $13.0(\mathrm{Zn}) \mu \mathrm{g} / \mathrm{L}$, and to a high morality at $10.6(\mathrm{Cu}), 9.0(\mathrm{~Pb})$ and $101.1(\mathrm{Zn}) \mu \mathrm{g} / \mathrm{L}$, respectively. In $\mathrm{CHA}$ sample, $\mathrm{Cu}, \mathrm{Pb}$ and $\mathrm{Zn}$ concentrations although being slightly lower than in Cooper et al. ${ }^{[31]}$ could have led to the delayed (F2) reproductive defect showed in C. dubia. On the contrary, some studies observed a tolerance/acclimation of cladocerans to copper (1-35 $\mu \mathrm{g} / \mathrm{L})$ and zinc $(50 \mu \mathrm{g} / \mathrm{L})$ at environmental realistic concentration as found in CHA samples. ${ }^{[32,33]}$ Considering the high mortality rate observed in F1 parents (56\%), it could be possible that a resistance/acclimation of the neonates borne during the stormwater exposure appeared and led to a higher production of neonates at the last (F3) generation.

We can also note that a significant concentration (considering its PNEC value) of fluorene was measured in the two samples (respectively $3.45 \mu \mathrm{g} / \mathrm{L}$ and $5.95 \mu \mathrm{g} / \mathrm{L}$ in CHA and MIR samples). If the acute and chronic (e.g. reproduction) ecotoxicity of fluorene is known (e.g. C. dubia reproduction bioassay $\mathrm{CE}_{10}$ at $\left.25 \mu \mathrm{g} / \mathrm{L}\right)^{[36]}$, its mechanism of action remains unclear and its toxicity is difficult to predict because depending for example on light exposure (possible UV photo-activation of PAHs. ${ }^{[37]}$ The role of epigenetic events to explain obtained results cannot be excluded since it was demonstrated by Vandegehuchte et al. ${ }^{[38,39]}$ in another cladoceran organism (D. magna) that sub-lethal concentrations of some heavy metals (such as zinc) or organic compounds (such as the 5-azacytidine drug) could modify the methylation pattern and subsequent transcription of several genes without stability among several generations.

\section{CONCLUSION}

A battery of acute and chronic bioassays was implemented for the ecotoxicity assessment of stormwaters. No toxic effect was observed neither with any of the acute and chronic standardized bioassays applied (D. magna mobility, P. subcapitata and H. incongruens growth), nor with the $C$. 
dubia reproduction bioassay performed on one generation (NF ISO 20665 slightly amended). We modified the C. dubia reproduction bioassay to perform the test over three successive generations in order to evaluate if this could improve the battery sensitivity. This study is the first attempt to apply a multigenerational reproduction bioassay on $C$. dubia, for the toxicity detection of complex urban matrixes such as urban stormwaters. This work contributes to an issue of growing interest: the pollutant long-term effect assessment through a multi-generational approach, as recently proposed as part of a new OECD guideline targeting D. magna reproduction. ${ }^{[6]}$ Present results show that the $C$. dubia three generation reproduction bioassay appears to be a relevant approach, since exposure of the second and third generations enables to reveal a disturbance of some fitness parameters (reproduction and mortality). In order to confirm the interest and thus the added value of such a multigenerational reproduction assay it is now necessary to complete the development of the assay (e.g. by studying changes in the size, weight, and/ or other physiological defects of $C$. dubia parents and neonates).

\section{ACKNOWLEDGEMENT}

Authors would like to thank Mathilde Inglot for her technical assistance. This work has been financially supported by the French Minister of Ecology and Sustainable Development, the French Minister of Higher Education and Research and the Field Observatory in Urban Hydrology (OTHU).

\section{CONFLICT OF INTEREST}

The authors declare that they have no competing interests. 
361

362

363

[1] Angerville, R.; Perrodin, Y.; Bazin, C.; Emmanuel, E. Evaluation of Ecotoxicological Risks Related to the Discharge of Combined Sewer Overflows (CSOs) in a Periurban River. International Journal of Environmental Research and Public Health, 2013, 10, 2670-2687.

[2] Gosset, A.; Ferro, Y.; Durrieu, C. Methods for evaluating the pollution impact of urban wet weather discharges on biocenosis: A review. Water Research, 2016, 89, 330-354.

[3] Rodríguez, E.M.; Medesani, D.A.; Fingerman, M. Endocrine disruption in crustaceans due to pollutants: a review. Comparative Biochemistry and Physiology Part A: Molecular \& Integrative Physiology, 2007, 146(4), 661-671

[4] Dang, Z.; Cheng, Y.; Chen, H.M.; Cui, Y.; Yin, H.H.; Traas, T.; Montforts, M.; Vermeire, T.

Evaluation of the Daphnia magna reproduction test for detecting endocrine disruptors. Chemosphere, 2012, 88(4), 514-523.

[5] Fong, P.P.; Ford, A.T. The biological effects of antidepressants on the molluscs and crustaceans: a review. Aquatic Toxicology, 2014, 151, 4-13.

[6] Barata, C.; Campos, B.; Rivettiantoine, C.; LeBlanc, G.A.; Eytcheson, S.; McKnight, S.; ToborKaplon, M.; de Vries Buitenweg, S.; Choi, S.; Choi, J.; Sarapultseva, E.I.; Coutellec, M.A.; Coke, M.; Pandard, P.; Chaumont, A.; Quéau, H.; Delorme, N.; Geffard, O.; Martinez-Jeronimo, F.; Watanabe, H.; Tatarazako, N.; Lopes, I.; Pestana, J.L.T.; Soares, A.M.V.M.; Pereira, C.M. Validation of a twogenerational reproduction test in Daphnia magna: An interlaboratory exercise. Science of The Total Environment, 2017, 579, 1073-1083

[7] Campos, B.; Rivetti, C.; Kress, T.; Barata, C.; Dircksen H. Depressing antidepressant: Fluoxetine affects serotonin neurons causing adverse reproductive responses in Daphnia magna. Environmental science \& technology, 2016, 50(11), 6000-6007.

[8] Rose, R.M.; Warne, M.S.J.; Lim, R.P. Residual effects of 3, 4-dichloroaniline on offspring born to Ceriodaphnia cf. dubia exposed for multiple generations. Journal of Aquatic Ecosystem Stress and Recovery, 2002, 9(3), 205-211. 
[9] Rose, R.M.; Warne, M.S.J.; Lim, R.P. Sensitivity of offspring to chronic 3, 4-dichloroaniline exposure varies with maternal exposure. Ecotoxicology and environmental safety, 2004, 58(3), 405412.

[10] Lamichhane, K.; Garcia, S.N.; Huggett, D.B.; DeAngelis, D.L.; La Point, T.W. Chronic effects of carbamazepine on life-history strategies of Ceriodaphnia dubia in three successive generations. Archives of environmental contamination and toxicology, 2013, 64(3), 427-438.

[11] Lamichhane, K.; Garcia, S.N.; Huggett, D.B.; DeAngelis, D.L.; La Point, T.W. Exposures to a selective serotonin reuptake inhibitor (SSRI), sertraline hydrochloride, over multiple generations: Changes in life history traits in Ceriodaphnia dubia. Ecotoxicology and environmental safety, 2014, $101,124-130$

[12] AFNOR. Qualité de l'eau - Détermination de la toxicité chronique vis-à-vis de Ceriodaphnia dubia. NF ISO 20665, 2009, 32p.

[13] El-Mufleh, A.; Béchet, B.; Ruban, V.; Legret, M.; Clozel, B.; Barraud, S.; Gonzalez-Merchan, C.; Bedell, J.-P.; Delolme, C. Review on physical and chemical characterizations of contaminated sediments from urban stormwater infiltration basins within the framework of the French observatory for urban hydrology (SOERE URBIS). Environmental Science and Pollution Research, 2014, 21(8), 5329-5346.

[14] AFNOR. Détermination de l'inhibition de croissance de Scenedesmus subspicatus et de Selenastrum capricornutum par une substance. Norme experimentale NT90-304; Association Française de Normalisation: Paris, France, 1980.

[15] OECD OECD GUIDELINES FOR THE TESTING OF CHEMICALS: Freshwater Alga and Cyanobacteria, Growth Inhibition Test. 2006.

[16] AFNOR. Qualité de l'eau - Détermination de la toxicité des sédiments d'eau douce envers Heterocypris incongruens (Crustacea, Ostracoda). NF ISO 14371, 2012, 16 p.

[17] AFNOR. Qualité de l'eau - Détermination de l'inhibition de la mobilité de Daphnia magna Straus (Cladocera, Crustacea). NF EN ISO 6341, 2012, 24p. 
[18] Zgheib, S.; Moilleron, R.; Saad, M.; Chebbo, G. Partition of pollution between dissolved and

particulate phases: what about emerging substances in urban stormwater catchments? Water Research, 2011, 45(2), 913-925.

[19] Zgheib, S.; Moilleron, R.; Chebbo, G. Priority pollutants in urban stormwater: Part 1-Case of separate storm sewers. Water research, 2012, 46(20), 6683-6692.

[20] Waara, S.; Färm, C. An assessment of the potential toxicity of runoff from an urban roadscape during rain events. Environmental Science and Pollution Research, 2008, 15(3), 205-210.

[21] Bi, E.G.; Monette, F.; Gasperi, J.; Perrodin, Y. (2015) Assessment of the ecotoxicological risk of combined sewer overflows for an aquatic system using a coupled "substance and bioassay" approach. Environmental Science and Pollution Research, , 22(6), 4460-4474.

[22] Wigh, A.; Devaux, A.; Brosselin, V.; Gonzalez-Ospina, A.; Domenjoud, B.; Aït-Aïssa, S.; Creusot, N.; Gosset, A.; Bazin, C.; Bony, S. Proposal to optimize ecotoxicological evaluation of wastewater treated by conventional biological and ozonation processes. Environmental Science and Pollution Research, 2015, 1-10.

[23] Sterner R.W. Modelling interactions of food quality and quantity in homeostatic consumers. Freshwater Biol, 1997, 38, 473-481.

[24] Elser, J.J.; Bracken, M.E.; Cleland, E.E.; Gruner, D.S.; Harpole, W.S.; Hillebrand, H.; Ngai, J.T.; Seabloom, E.W.; Shurin, J.B.; Smith, J.E. Global analysis of nitrogen and phosphorus limitation of primary producers in freshwater, marine and terrestrial ecosystems. Ecol Lett, 2007, 10, 1135-1142. [25] Civitello, D.J.; Hite, J.L.; Hall, S.R. Potassium enrichment stimulates the growth and reproduction of a clone of Daphnia dentifera. Oecologia, 2014, 175(3), 773-780.

[26] Pandard P. Ceriodaphnia dubia population growth inhibition. Influence of modification of the experimental protocol on the validity of the tests. INERIS Technical report. Ministry of Ecology and Sustainable Development. Water Directorate, 2003, 9p. [27] Kayhanian, M.; Stransky, C.; Bay, S.; Lau, S.-L.; Stenstrom, M.K. Toxicity of urban highway runoff with respect to storm duration. Science of The Total Environment , 2008, 389, 386-406. 
[28] McQueen, A.D.; Johnson, B.M.; Rodgers, J.H.; English, W.R. Campus parking lot stormwater runoff: Physicochemical analyses and toxicity tests using Ceriodaphnia dubia and Pimephales promelas. Chemosphere, 2010, 79(5), 561-569.

[29] Richard, S., Moslemi, S., Sipahutar, H., Benachour, N., Seralini, G.E. Differential effects of glyphosate and roundup on human placental cells and aromatase. Environmental health perspectives, 2005, 716-720.

[30] Cuhra, M.; Traavik, T.; Bøhn, T. Clone-and age-dependent toxicity of a glyphosate commercial formulation and its active ingredient in Daphnia magna. Ecotoxicology, 2013, 22(2), 251-262.

[31] Cooper, N.L.; Bidwell, J.R.; Kumar, A. Toxicity of copper, lead, and zinc mixtures to Ceriodaphnia dubia and Daphnia carinata. Ecotoxicology and Environmental Safety, 2009, 72(5), $1523-1528$.

[32] Bossuyt B.T.; Janssen C.R. Acclimation of Daphnia magna to environmentally realistic copper concentrations. Comparative Biochemistry and Physiology Part C: Toxicology \& Pharmacology, 2002, 136(3), 253-264.

[33] Muyssen, B.T.; Janssen, C.R. Tolerance and acclimation to zinc of Ceriodaphnia dubia. Environmental pollution, 2002, 117(2), 301-306.

[36] INERIS. Portail Substances Chimiques. Available online: http://www.Ineris.Fr/fr/rapportsd\%c3\%a9tude/toxicologie-et-environnement/fiches-de donn\%c3\%a9es-toxicologiques-etenvironnementales (last access on July, 16 ${ }^{\text {nd }} 2016$ ). [37] Lampi, M.A.; Gurska, J.; McDonald, K.I.; Xie, F.; Huang, X.D.; Dixon, D.G.; Greenberg, B.M. Photoinduced toxicity of polycyclic aromatic hydrocarbons to Daphnia magna: Ultraviolet-mediated effects and the toxicity of polycyclic aromatic hydrocarbon photoproducts. Environmental toxicology and chemistry, 2006, 25(4), 1079-1087.

[38] Vandegehuchte, M.B.; Lemière, F.; Janssen, C.R. Quantitative DNA-methylation in Daphnia magna and effects of multigeneration Zn exposure. Comparative Biochemistry and Physiology Part C: Toxicology \& Pharmacology, 2009, 150(3), 343-348.

[39] Vandegehuchte, M.B.; Lemière, F.; Vanhaecke, L.; Berghe, W.V.; Janssen, C.R. Direct and transgenerational impact on Daphnia magna of chemicals with a known effect on DNA methylation. 
466 Comparative Biochemistry and Physiology Part C: Toxicology \& Pharmacology, 201à, 151(3), 278-

467285.

468

469

470

471

472

473

474

475

476

477

478

479

480

481

482

483

484

485

486 
Table 1: Characteristics of the rain events corresponding to stormwater samples.

Table 2: Chemical analyzes of urban stormwater samples.

490

491

Table 3: Daphnia magna immobilization and $P$. subcapitata growth inhibition tests: $\mathrm{EC}_{20}$ values after 24 and $48 \mathrm{~h}$ exposure of D. magna $(\mathrm{n}=4)$ and $72 \mathrm{~h}$ exposure of $P$. subcapitata $(\mathrm{n}=3)$.

Table 4: Percentage of mortality in Ceriodaphnia dubia parents (F0, F1 and F2) along the exposure to wastewater samples and to control medium. Limit of significance is $20 \%$ (from AFNOR standard, 2009).

Figure 1: Exposure protocol of three successive generations in Ceriodaphnia dubia.

Figure 2: Heterocypris incongruens growth inhibition assay. Six replicates of 10 organisms were performed per assay. Histograms represent the mean growth of control neonates or neonates exposed to stormwater. Bars show standard errors $(n=6)$. Asterisks indicate a significant difference from the control $(* \mathrm{p}<0.05, * * \mathrm{p}<0.01, * * * \mathrm{p}<0.001)$.

Figure 3: Multigenerational Ceriodaphnia dubia bioassay. The stormwater concentration tested is 90\%. Effect on population growth is expressed as the mean of variation percentage compared to control of 12 replicates \pm standard deviation. Effect on population reproduction is expressed as the mean of variation percentage compared to the control for the $n$ surviving mothers \pm standard deviation. Dotted lines represent the significance limit of 30\% established in NF ISO 20665 standard. Asterisks indicate a statistical significant difference from the control $(* \mathrm{p}<0.05$, ** $\mathrm{p}<0.01$, *** $\mathrm{p}<0.001)$. 
Table 1: Characteristics of the rain events corresponding to stormwater samples.

511

\begin{tabular}{ccccc}
\hline $\begin{array}{c}\text { Sample } \\
\text { name }\end{array}$ & $\begin{array}{c}\text { Rain event duration } \\
(\mathrm{hh}: \mathrm{min})\end{array}$ & $\begin{array}{c}\text { Rain } \\
\text { height }(\mathrm{mm})\end{array}$ & $\begin{array}{c}\text { Rain } \\
\text { intensity }\left(\mathrm{mm} \cdot \mathrm{h}^{-1}\right)\end{array}$ & $\begin{array}{c}\text { Dry period before rain } \\
\text { event (dd:hh:min) }\end{array}$ \\
\hline CHA & $20: 06$ & 17.2 & 0.86 & $03: 03: 48$ \\
MIR & $04: 30$ & 5.4 & 1.20 & $01: 22: 30$ \\
\hline
\end{tabular}

512

513

514

515

516

517

518

519

520

521

522

523

524

525

526

527

528

529 
Table 2: Chemical analyzes of urban stormwater samples.

\begin{tabular}{|c|c|c|c|c|}
\hline Parameter & Unit & CHA sample & MIR sample & $\begin{array}{c}\text { Freshwater Aquatic PNEC }{ }^{[36]} \\
\text { (From INERIS) }\end{array}$ \\
\hline $\mathrm{pH}$ & - & 8.0 & 7.2 & I \\
\hline Conductivity & $\mu \mathrm{S} / \mathrm{cm}$ & 103.6 & 105.1 & l \\
\hline TSS & $\mathrm{mg} / \mathrm{L}$ & 82 & 56.26 & I \\
\hline DOC & $\mathrm{mg} / \mathrm{L}$ & 7.1 & 6.53 & I \\
\hline $\mathrm{NO}_{3}^{-}$ & $\mathrm{mg} / \mathrm{L}$ & 1.6 & 7.0 & l \\
\hline $\mathrm{NH}_{4}^{+}$ & $\mathrm{mg} / \mathrm{L}$ & 1.1 & 0.3 & I \\
\hline $\mathrm{SO}_{4}^{2-}$ & $\mathrm{mg} / \mathrm{L}$ & 0.3 & 3.4 & I \\
\hline $\mathrm{Cl}^{-}$ & $\mathrm{mg} / \mathrm{L}$ & 0.7 & 1.6 & I \\
\hline $\mathrm{PO}_{4}^{3-}$ & $\mathrm{mg} / \mathrm{L}$ & 0.01 & 0.3 & l \\
\hline $\mathrm{K}^{+}$ & $\mathrm{mg} / \mathrm{L}$ & 1.27 & 3.3 & I \\
\hline \multicolumn{5}{|l|}{$\underline{\text { Metals }}$} \\
\hline $\mathrm{Pb}$ & $\mu \mathrm{g} / \mathrm{L}$ & 0.10 & $<0.05^{*}$ & 5 \\
\hline $\mathrm{Cr}$ & $\mu \mathrm{g} / \mathrm{L}$ & 0.63 & 0.31 & 4.7 \\
\hline $\mathrm{Ni}$ & $\mu \mathrm{g} / \mathrm{L}$ & 1.23 & 0.59 & 1.7 \\
\hline $\mathrm{Cd}$ & $\mu \mathrm{g} / \mathrm{L}$ & 0.09 & $<0.002$ & 0.19 \\
\hline $\mathrm{Cu}$ & $\mu \mathrm{g} / \mathrm{L}$ & 12.48 & 4.38 & 1.6 \\
\hline $\mathrm{Fe}$ & $\mathrm{mg} / \mathrm{L}$ & $<0.005$ & $<0.006$ & I \\
\hline $\mathrm{Ca}$ & $\mathrm{mg} / \mathrm{L}$ & 20,42 & 25,51 & l \\
\hline $\mathrm{Zn}$ & $\mathrm{mg} / \mathrm{L}$ & 0.08 & 0.02 & 0.0078 \\
\hline \multicolumn{5}{|l|}{ Organic compounds\# } \\
\hline Benzyle chloride & $\mu \mathrm{g} / \mathrm{L}$ & $<0.1$ & 0.5 & 1 \\
\hline Fluorene & $\mu \mathrm{g} / \mathrm{L}$ & 3.45 & 5.93 & 0.25 \\
\hline AMPA & $\mu \mathrm{g} / \mathrm{L}$ & 0.98 & 20.15 & 80 \\
\hline Glyphosate & $\mu \mathrm{g} / \mathrm{L}$ & $<0.5$ & 69.25 & 28 \\
\hline Fosetyl-aluminium & $\mu \mathrm{g} / \mathrm{L}$ & 2.6 & $<0.5$ & 590 \\
\hline Tributyl phosphate & $\mu \mathrm{g} / \mathrm{L}$ & 0.12 & $<0.05$ & 82 \\
\hline
\end{tabular}

531 PNEC (Predicted No Effect Concentration), TSS (Total Suspended Solids), DOC (Dissolved Organic

532 Carbon), AMPA (2-Amino-3-(3-hydroxy-5-Methyl-isoxazol-4-yl)Propanoic Acid), / : no data available.

$533 *:<$ limit of quantification. \# : organic chemicals listed here are those detected at a level $\geq$ limit of

534 quantification among 105 compounds analyzed. 
536 Table 3: D. magna immobilization and $P$. subcapitata growth inhibition tests: $\mathrm{EC}_{20}$ values after 24

537 and $48 \mathrm{~h}$ exposure of $D$. magna $(\mathrm{n}=4)$ and $72 \mathrm{~h}$ exposure of $P$. subcapitata $(\mathrm{n}=3)$.

\begin{tabular}{ccc}
\hline & CHA sample & MIR sample \\
\hline Daphnia magna bioassay & & \\
$\mathrm{EC}_{20-24 \mathrm{~h}}$ & $>90 \%$ & $>90 \%$ \\
$\mathrm{EC}_{20-48 \mathrm{~h}}$ & $>90 \%$ & $>90 \%$ \\
$\frac{\text { Pseudokirchneriella subcapitata bioassay }}{\mathrm{EC}_{20-72 \mathrm{~h}}}$ & $>90 \%$ & $>90 \%$ \\
\hline
\end{tabular}

539

540

541 Table 4: Percentage of mortality in Ceriodaphnia dubia parents (F0, F1 and F2) along the exposure to

542 wastewater samples and to control medium. Limit of significance is $20 \%$ (from AFNOR standard,

543 2009).

\begin{tabular}{cccc}
\hline & Control & CHA & MIR 544 \\
\hline F0 & 0 & 8.33 & 8.33 \\
F1 & 0 & $\mathbf{5 4 . 5 4}$ & $8.33{ }^{545}$ \\
F2 & 0 & 0 & $\mathbf{8 0}_{546}$ \\
\hline
\end{tabular}

547

548

549

550

551

552

553

554 


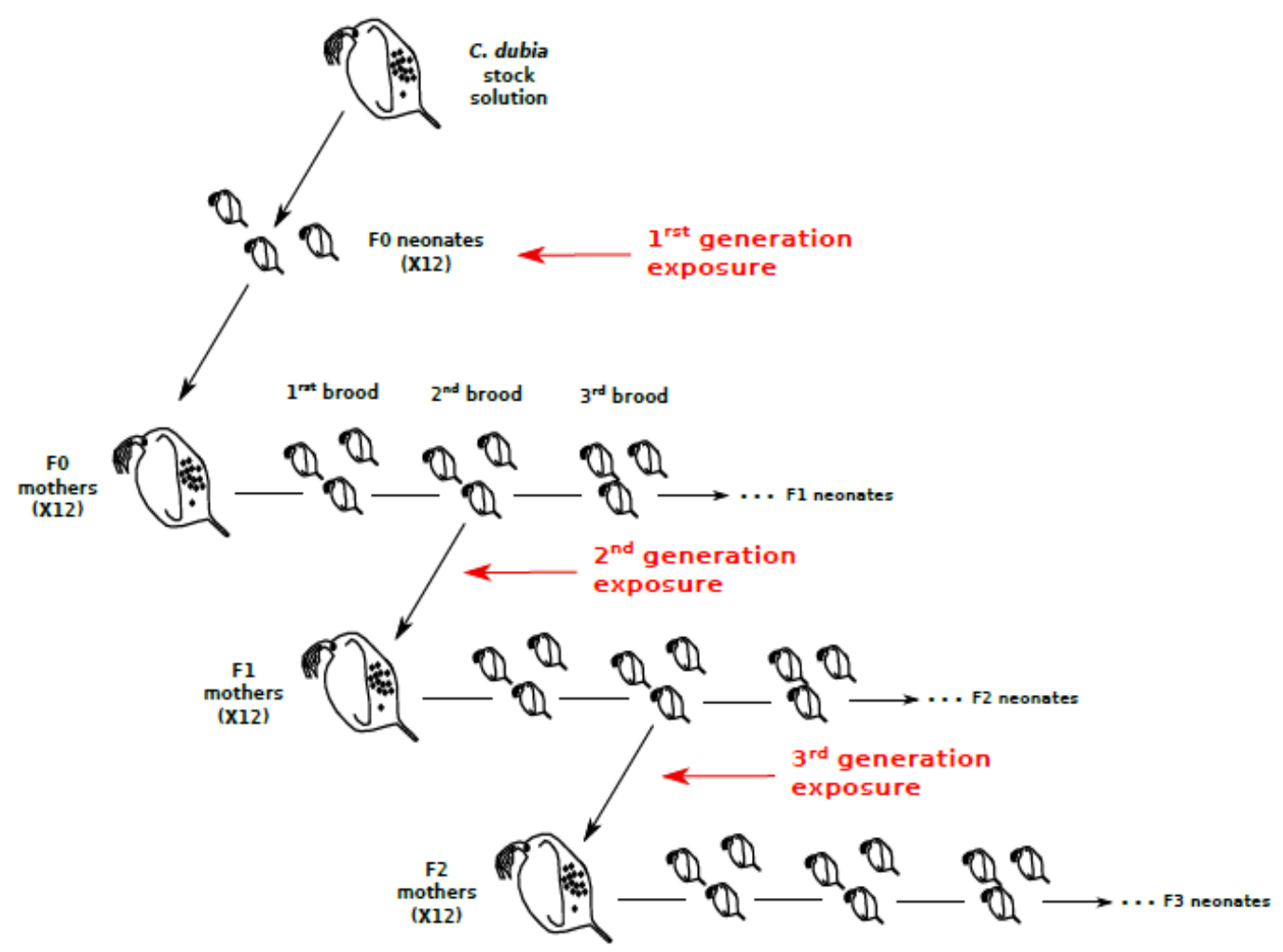

Figure 1: Exposure protocol of three successive generations in Ceriodaphnia dubia. 


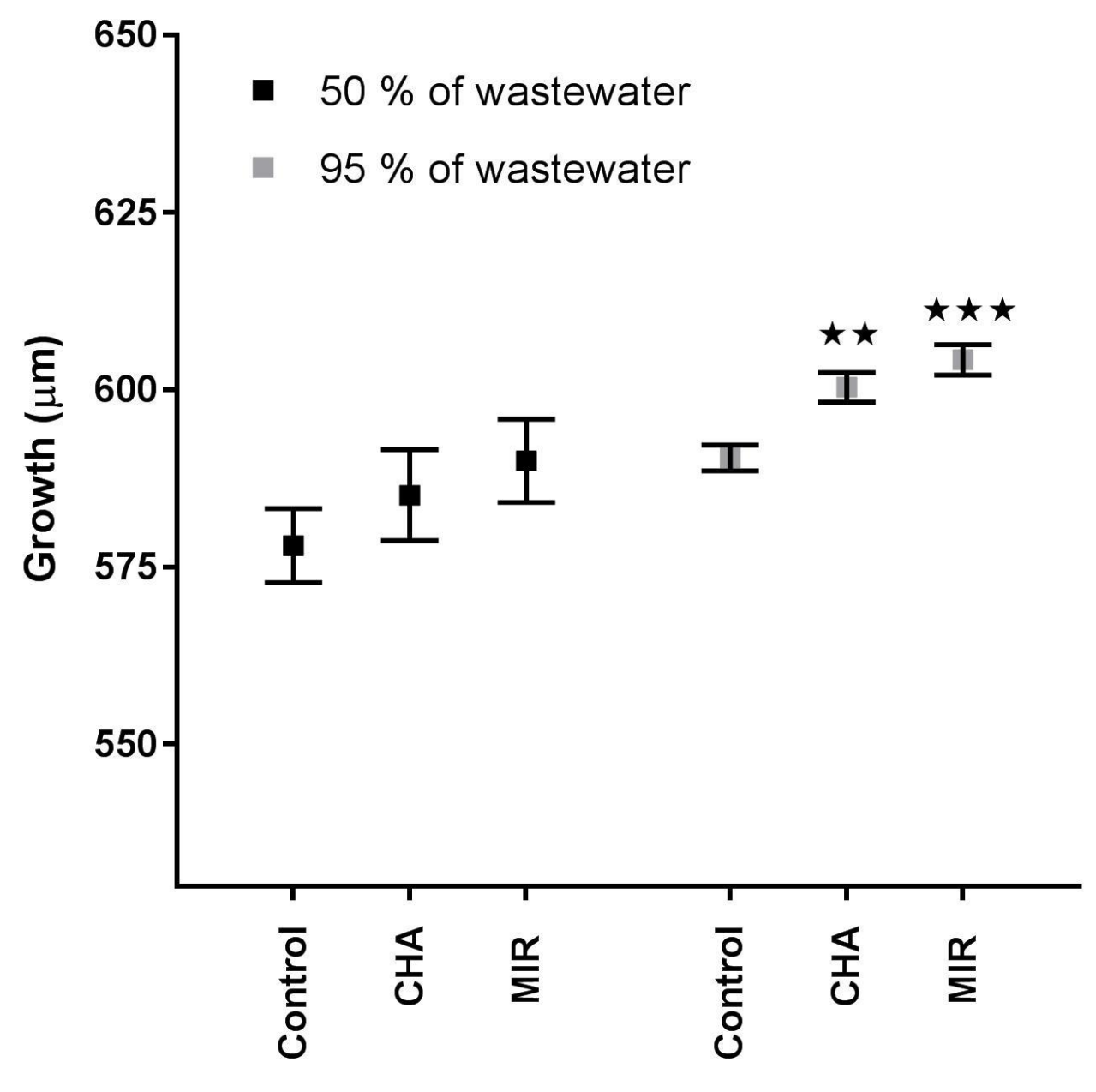

577 Figure 2: Heterocypris incongruens growth inhibition assay. Six replicates of 10 organisms were

578 performed per assay. Histograms represent the mean growth of control neonates or neonates exposed 579 to stormwater. Bars show standard errors $(n=6)$. Asterisks indicate a significant difference from the 580 control $(* \mathrm{p}<0.05, * * \mathrm{p}<0.01, * * * \mathrm{p}<0.001)$.

581

582

583 
(CHA)

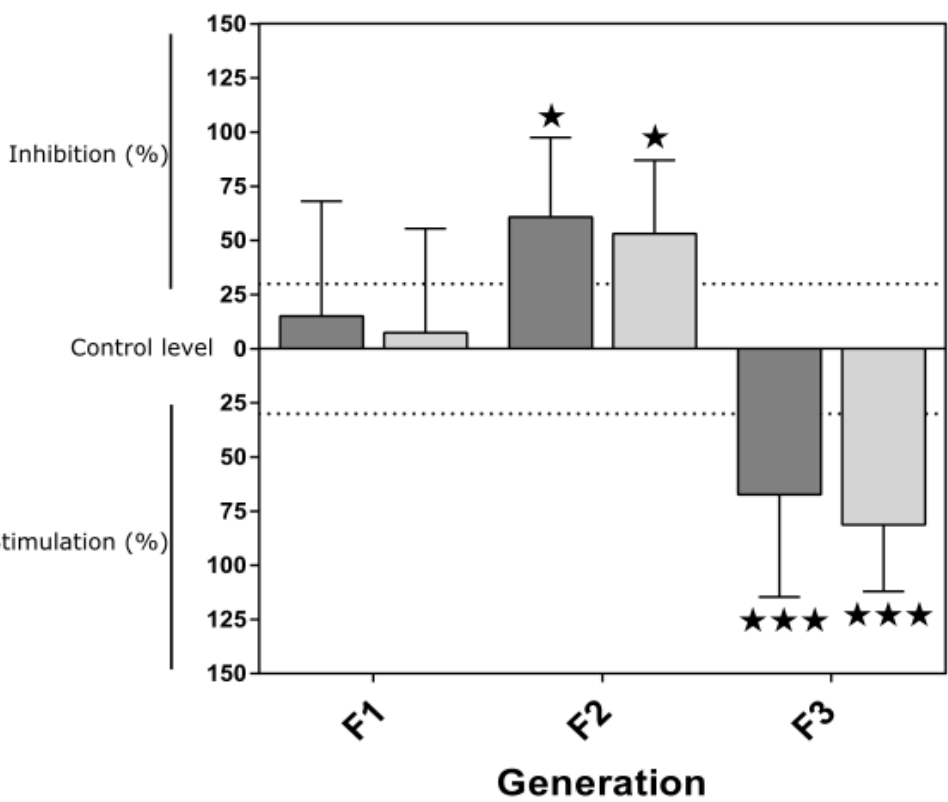

(MIR)

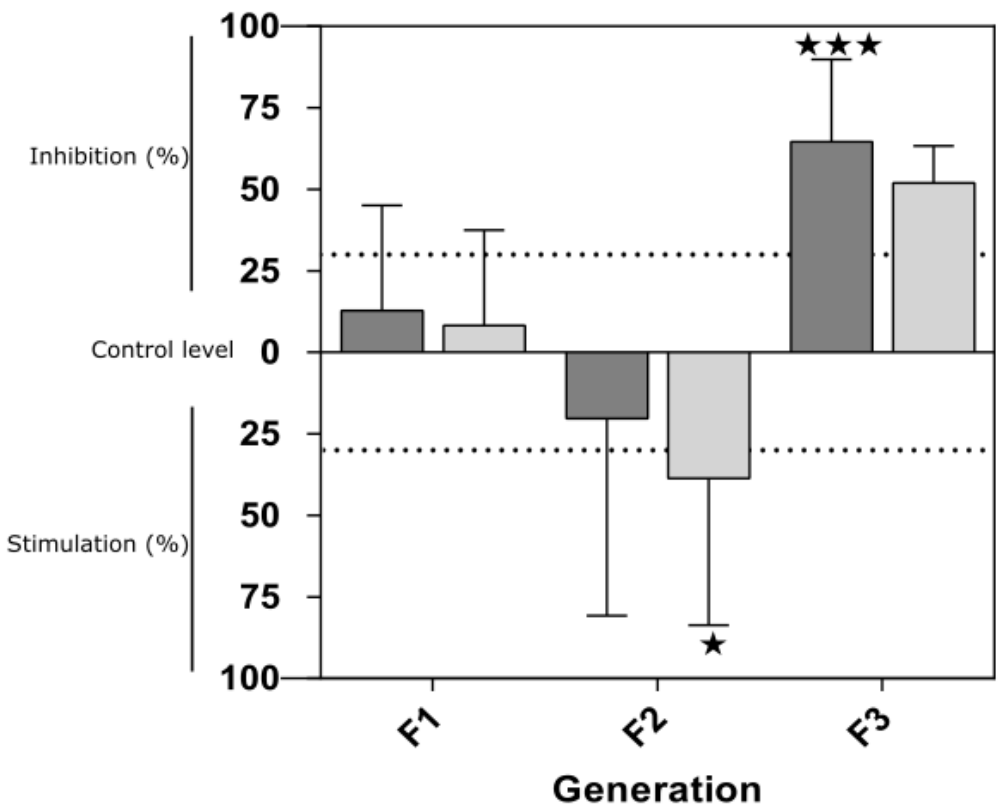

Figure 3: Multigenerational Ceriodaphnia dubia bioassay. The stormwater concentration tested is $90 \%$. Effect on population growth is expressed as the mean of variation percentage compared to control of 12 replicates \pm standard deviation. Effect on population reproduction is expressed as the mean of variation percentage compared to the control for the $\mathrm{n}$ surviving mothers \pm standard deviation. Dotted lines represent the significance limit of 30\% established in NF ISO 20665 standard. Asterisks indicate a statistical significant difference from the control $(* \mathrm{p}<0.05, * * \mathrm{p}<0.01, * * * \mathrm{p}<0.001)$. 
600 Supplementary table 1: List of the organic compounds, analytical methods and standards used for stormwater physico-chemical analyses in this study.

\begin{tabular}{|c|c|c|}
\hline Compound & Analytical method used & Standard \\
\hline \multicolumn{3}{|l|}{ VOC : Volatil Organic Compounds } \\
\hline 1,1,2,2-tetrachloroethane & HS/GC/MS & NF EN ISO 10301 \\
\hline 1,1,1-trichloroethane & $\mathrm{HS} / \mathrm{GC} / \mathrm{MS}$ & NF EN ISO 10301 \\
\hline 1,1,2-trichloroethane & $\mathrm{HS} / \mathrm{GC} / \mathrm{MS}$ & NF EN ISO 10301 \\
\hline 1,1-dichloroethane & $\mathrm{HS} / \mathrm{GC} / \mathrm{MS}$ & NF EN ISO 10301 \\
\hline 1,1-dichloroethylene & $\mathrm{HS} / \mathrm{GC} / \mathrm{MS}$ & NF EN ISO 10301 \\
\hline 1,2-dichloroethane & $\mathrm{HS} / \mathrm{GC} / \mathrm{MS}$ & NF EN ISO 10301 \\
\hline Cis 1,2-dichloroéthylene & $\mathrm{HS} / \mathrm{GC} / \mathrm{MS}$ & NF EN ISO 10301 \\
\hline Trans 1,2-dichloroethylene & $\mathrm{HS} / \mathrm{GC} / \mathrm{MS}$ & NF EN ISO 10301 \\
\hline 1-chloronaphtalene & GC/MS after $\mathrm{CH} 2 \mathrm{Cl} 2$ liquid-liquid extraction & Internal method \\
\hline 2-chloronaphtalene & GC/MS after $\mathrm{CH} 2 \mathrm{Cl} 2$ liquid-liquid extraction & Internal method \\
\hline Vinyl chlorid & $\mathrm{HS} / \mathrm{GC} / \mathrm{MS}$ & NF EN ISO 10301 \\
\hline Dichloromethane & $\mathrm{HS} / \mathrm{GC} / \mathrm{MS}$ & NF EN ISO 10301 \\
\hline Hexachlorobutadiene & GC/MS after $\mathrm{CH} 2 \mathrm{Cl} 2$ liquid-liquid extraction & Internal method \\
\hline Pentachloroethane & GC/MS after $\mathrm{CH} 2 \mathrm{Cl} 2$ liquid-liquid extraction & Internal method \\
\hline Tétrachloroethylene & $\mathrm{HS} / \mathrm{GC} / \mathrm{MS}$ & NF EN ISO 10301 \\
\hline Carbon tetrachloride & $\mathrm{HS} / \mathrm{GC} / \mathrm{MS}$ & NF EN ISO 10301 \\
\hline Trichloroethylene & $\mathrm{HS} / \mathrm{GC} / \mathrm{MS}$ & NF EN ISO 10301 \\
\hline Sum of tri and tetrachlorethylene & $\mathrm{HS} / \mathrm{GC} / \mathrm{MS}$ & NF EN ISO 10301 \\
\hline Sum of 1,2-dichloroethylene & $\mathrm{HS} / \mathrm{GC} / \mathrm{MS}$ & NF EN ISO 10301 \\
\hline Autres & & \\
\hline Dichlorobenzidine & GC/MS after $\mathrm{CH} 2 \mathrm{Cl} 2$ liquid-liquid extraction & Internal method \\
\hline Benzidine & $\mathrm{GC} / \mathrm{MS}$ after $\mathrm{CH} 2 \mathrm{Cl} 2$ liquid-liquid extraction & Internal method \\
\hline Benzyl chlorid & $\mathrm{GC} / \mathrm{MS}$ after $\mathrm{CH} 2 \mathrm{Cl} 2$ liquid-liquid extraction & Internal method \\
\hline benzylidene chlorid & $\mathrm{GC} / \mathrm{MS}$ after $\mathrm{CH} 2 \mathrm{Cl} 2$ liquid-liquid extraction & Internal method \\
\hline 4-chloroacetanilide & GC/MS after $\mathrm{CH} 2 \mathrm{Cl} 2$ liquid-liquid extraction & Internal method \\
\hline \multicolumn{3}{|l|}{ PAH : Polycyclic Aromatic } \\
\hline \multicolumn{3}{|l|}{ Hydrocarbons } \\
\hline Fluoranthene & HPLC/FLUO & NFT90-115 \\
\hline Benzo (b) fluoranthene & HPLC/FLUO & NFT90-115 \\
\hline Benzo (k) fluoranthene & HPLC/FLUO & NFT90-115 \\
\hline Benzo (a) pyrene & HPLC/FLUO & NFT90-115 \\
\hline Benzo (ghi) perylene & HPLC/FLUO & NFT90-115 \\
\hline Indeno $(1,2,3 \mathrm{~cd})$ pyrene & HPLC/FLUO & NFT90-115 \\
\hline Anthracene & HPLC/FLUO & NFT90-115 \\
\hline Acénaphtene & HPLC/FLUO & NFT90-115 \\
\hline Chrysene & HPLC/FLUO & NFT90-115 \\
\hline Dibenzo $(\mathrm{a}, \mathrm{h})$ anthracene & HPLC/FLUO & NFT90-115 \\
\hline Fluorene & HPLC/FLUO & NFT90-115 \\
\hline Naphtalene & HPLC/FLUO & NFT90-115 \\
\hline Pyrene & HPLC/FLUO & NFT90-115 \\
\hline Phenanthrene & HPLC/FLUO & NFT90-115 \\
\hline Benzo (a) anthracene & HPLC/FLUO & NFT90-115 \\
\hline \multicolumn{3}{|l|}{ Pesticides } \\
\hline Nitrogen Pesticides & & \\
\hline$\overline{\text { Atrazine }}$ & GC/MS/MS after liquid-liquid extraction & ISO 6468, NF EN 12918, ISO 10695 \\
\hline Simazine & GC/MS/MS after liquid-liquid extraction & ISO 6468, NF EN 12918, ISO 10695 \\
\hline Organochlorine Pesticides & & \\
\hline$\overline{\text { Lindane }(\gamma-\mathrm{HCH})}$ & GC/MS/MS after liquid-liquid extraction & ISO 6468, NF EN 12918, ISO 10695 \\
\hline$\alpha-\mathrm{HCH}$ & GC/MS/MS after liquid-liquid extraction & ISO 6468, NF EN 12918, ISO 10695 \\
\hline Aldrin & GC/MS/MS after liquid-liquid extraction & ISO 6468, NF EN 12918, ISO 10695 \\
\hline Dieldrin & GC/MS/MS after liquid-liquid extraction & ISO 6468, NF EN 12918, ISO 10695 \\
\hline Endrin & GC/MS/MS after liquid-liquid extraction & ISO 6468, NF EN 12918, ISO 10695 \\
\hline $2,4^{\prime}-\mathrm{DDT}$ & GC/MS/MS after liquid-liquid extraction & ISO 6468, NF EN 12918, ISO 10695 \\
\hline 4,4'-DDT & GC/MS/MS after liquid-liquid extraction & ISO 6468, NF EN 12918, ISO 10695 \\
\hline
\end{tabular}


Isodrin

$\beta-\mathrm{HCH}$

$\delta$ - $\mathrm{HCH}$

Endosulfan

Heptachlor

2,4'-DDD

4,4'-DDD

2,4'-DDE

4,4'-DDE

(cis+trans) Chlordane

Sum of $\mathrm{HCH}$ isomers (except $\varepsilon-\mathrm{HCH}$ )

$\varepsilon-\mathrm{HCH}$

Chlordecone

Organophosphorus pesticides

Chlorfenvinfos

Ethyl-Chlorpyrifos

Pesticides (others)

AMPA

Glyphosate

Fosetyl-aluminium

Alachlor

Trifluralin

Oxadiazon

Biphenyl

Substituted urea

Diuron

Isoproturon

Chlorotoluron

Linuron

\section{Benzene derivatives}

Chlorobenzenes

1,2,4,5-tetrachlorobenzene

Hexachlorobenzene

Pentachlorobenzene

Monochlorobenzene

Bromobenzene

2-chlorotoluene

3 -chlorotoluene

4-chlorotoluene

1,2-dichlorobenzene

1,3-dichlorobenzene

1,4-dichlorobenzene

1,2,4-trichlorobenzene

1,3,5-trichlorobenzene

Sum of trichlorobenzenes

Sum of dichlorobenzenes

Sum of monochlorotoluenes

Chloronitrobenzenes

1-chloro, 4-nitrobenzene

1-chloro, 2-nitrobenzene

1-chloro, 3-nitrobenzene

Phenol derivatives

Chlorophenols

2-chlorophenol

3-chlorophenol

4-chlorophenol

2,4-dichlorophenol

2,4,5-trichlorophenol

2,4,6-trichlorophenol

Pentachlorophenol

Alkylphenols

4-n nonylphenol

4-n octylphenol

4-tert octylphenol

Sum of octylphenols

Nonylphenol (CAS 25154-52-3)
GC/MS/MS after liquid-liquid extraction GC/MS/MS after liquid-liquid extraction GC/MS/MS after liquid-liquid extraction GC/MS/MS after liquid-liquid extraction GC/MS/MS after liquid-liquid extraction GC/MS/MS after liquid-liquid extraction GC/MS/MS after liquid-liquid extraction GC/MS/MS after liquid-liquid extraction GC/MS/MS after liquid-liquid extraction GC/MS/MS after liquid-liquid extraction GC/MS/MS after liquid-liquid extraction GC/MS/MS after liquid-liquid extraction GC/MS/MS after liquid-liquid extraction

GC/MS/MS after liquid-liquid extraction GC/MS/MS after liquid-liquid extraction

HPLC/MS/MS after direct injection HPLC/MS/MS after direct injection HPLC/MS/MS after direct injection GC/MS/MS after liquid-liquid extraction GC/MS/MS after liquid-liquid extraction GC/MS/MS after liquid-liquid extraction GC/MS/MS after liquid-liquid extraction

HPLC/DAD after liquid-liquid extraction HPLC/DAD after liquid-liquid extraction HPLC/DAD after liquid-liquid extraction HPLC/DAD after liquid-liquid extraction

GC/MS/MS after liquid-liquid extraction GC/MS/MS after liquid-liquid extraction GC/MS/MS after liquid-liquid extraction HS/GC/MS

$\mathrm{HS} / \mathrm{GC} / \mathrm{MS}$

$\mathrm{HS} / \mathrm{GC} / \mathrm{MS}$

HS/GC/MS

$\mathrm{HS} / \mathrm{GC} / \mathrm{MS}$

$\mathrm{HS} / \mathrm{GC} / \mathrm{MS}$

$\mathrm{HS} / \mathrm{GC} / \mathrm{MS}$

$\mathrm{HS} / \mathrm{GC} / \mathrm{MS}$

$\mathrm{HS} / \mathrm{GC} / \mathrm{MS}$

$\mathrm{HS} / \mathrm{GC} / \mathrm{MS}$

HS/GC/MS

$\mathrm{HS} / \mathrm{GC} / \mathrm{MS}$

$\mathrm{HS} / \mathrm{GC} / \mathrm{MS}$

GC/MS/MS after liquid-liquid extraction GC/MS/MS after liquid-liquid extraction GC/MS/MS after liquid-liquid extraction

GC/MS/MS after acetylation and liquid-liquid extraction GC/MS/MS after acetylation and liquid-liquid extraction GC/MS/MS after acetylation and liquid-liquid extraction GC/MS/MS after acetylation and liquid-liquid extraction GC/MS/MS after acetylation and liquid-liquid extraction GC/MS/MS after acetylation and liquid-liquid extraction GC/MS/MS after acetylation and liquid-liquid extraction

GC/MS/MS after liquid-liquid extraction GC/MS/MS after liquid-liquid extraction GC/MS/MS after liquid-liquid extraction GC/MS/MS after liquid-liquid extraction GC/MS/MS after liquid-liquid extraction
ISO 6468, NF EN 12918, ISO 10695 ISO 6468, NF EN 12918, ISO 10695 ISO 6468, NF EN 12918, ISO 10695 ISO 6468, NF EN 12918, ISO 10695 ISO 6468, NF EN 12918, ISO 10695 ISO 6468, NF EN 12918, ISO 10695 ISO 6468, NF EN 12918, ISO 10695 ISO 6468, NF EN 12918, ISO 10695 ISO 6468, NF EN 12918, ISO 10695 ISO 6468, NF EN 12918, ISO 10695 ISO 6468, NF EN 12918, ISO 10695 ISO 6468, NF EN 12918, ISO 10695 ISO 6468, NF EN 12918, ISO 10695

ISO 6468, NF EN 12918, ISO 10695 ISO 6468, NF EN 12918, ISO 10695

Internal method

Internal method

Internal method

Internal method following NF EN 6468

Internal method following NF EN 6468

Internal method following NF EN 6468

Internal method following NF EN 6468

Internal method

Internal method

Internal method

Internal method

Internal method following NF EN 6468 Internal method following NF EN 6468 Internal method following NF EN 6468 NF EN ISO 11423-1

NF EN ISO 11423-1

NF EN ISO 11423-1

NF EN ISO 11423-1

NF EN ISO 11423-1

NF EN ISO 11423-1

NF EN ISO 11423-1

NF EN ISO 11423-1

NF EN ISO 11423-1

NF EN ISO 11423-1

NF EN ISO 11423-1

NF EN ISO 11423-1

NF EN ISO 11423-1

Internal method following NF EN 6468 Internal method following NF EN 6468 Internal method following NF EN 6468

Internal method following NF EN 12673 Internal method following NF EN 12673 Internal method following NF EN 12673 Internal method following NF EN 12673 Internal method following NF EN 12673 Internal method following NF EN 12673 Internal method following NF EN 12673

Internal method following NF EN ISO 18857-1 Internal method following NF EN ISO 18857-1 Internal method following NF EN ISO 18857-1 Internal method following NF EN ISO 18857-1 Internal method following NF EN ISO 18857-1 
Sum of nonylphenols

4-tert butylphenol

Other compounds

4,4'-biphenol

Tributyl phosphate

Hexachlorocyclopentadiene
GC/MS/MS after liquid-liquid extraction

GC/MS/MS after liquid-liquid extraction

GC/MS/MS after $\mathrm{CH} 2 \mathrm{Cl} 2$ liquid-liquid extraction

GC/MS/MS after liquid-liquid extraction

GC/MS/MS after liquid-liquid extraction
Internal method following NF EN ISO 18857-1

Internal method following NF EN ISO 18857-1

Internal method

Internal method following NF EN 6468

Internal method following NF EN 6468

DAD (Diode-Array Detection), FLUO (Fluorescence), GC (Gas Chromatography), HPLC (High Performance Liquid Chromatography), HS (HeadSpace), MS (Mass Spectrometry).

602 